\title{
Knowledge about Tuberculosis and its Complication among the Patients in a Teaching Hospital
}

Fazlu Rehman*, Raoof MA, Srinivasa Rao A, Ashfaq Hasan and Qurram M

Global College of Pharmacy, Hyderabad, India

\begin{abstract}
Tuberculosis (TB) is an infectious disease which is transmitted by air. This disease damages the lungs and other organs in the human body. It is one of the leading causes of morbidity and mortality despite the fact that it can be cured with adequate treatment. The entry of multidrug resistant tuberculosis (MDR-TB) or extensively drug resistant (XDRTB) is biggest challenges in our effort to control the disease complications. A cross-sectional study was conducted to assess TB related knowledge, its complications and control among the patients from the outpatient Pulmonology department of Owaisi Hospital and Research Center- HYD. The research shows that maximum number of patients $(59 \%)$ was unsure about the severe complication of TB whereas patients did not adhere to the treatment and discontinue it half-way, this become the prime reasons for the gap between treatment and control, thereby non-adherent treatment could have severe consequences of diseases and might lead to death. Knowledge about pulmonary complication and duration of treatment has to be emphasized.
\end{abstract}

Keywords: Pulmonary complication; Patient's perception; Treatment; Prevention and control

\section{Introduction}

After human immunodeficiency virus (HIV) [1-3], Tuberculosis (TB) is one of the leading causes of the disease worldwide $[4,5]$. The Latest World Health Organization (WHO) Report shows that there were 9.0 Million new TB cases and 1.5 Million tuberculosis deaths [6-10]. The Transmission of the TB disease by Mycobacterium tuberculosis takes place by air in the form of sneeze, talk, cough, spit etc. Transmission of the disease occurs only after continues exposure patients with active TB [11-13]. In some patients, the sign and symptoms of the disease do not appear for many years and TB bacteria remains dormant. The disease gets effect only if the immune system becomes weakened by Diabetes, HIV infection, Malignancy, Kidney disease and immunosuppressive agent [14-19].

Active or pulmonary tuberculosis (TB) can cause permanent lung damage when it is not diagnosed and treated early [12]. Untreated active disease can also spread to other organs of the body where it leads to serious or life-threatening complications. Complications of TB arise due to late detection, identification and irregular treatment. These complications can vary from mild to severe health problems that may also cause death [20-26]. Few complications of the disease are listed like permanent lung damage, Meningitis, bone and joint complications, cardiac problems and liver or renal inflammation [27-32].

Due to Multidrug resistance, some of the TB programs were not successful. Drug [9] resistance in MDR-TB or XDR-TB is a human-made problem [33-35]. Lack of awareness, incomplete [9] or inappropriate treatment and bad quality of medicines has led to the present situation of TB prevalence $[36,37]$. The early detection and proper treatment of TB using combination of drug therapies for 6-9 months can make the patient non-infectious and finally cure the disease [38,39]. However, in countries like India proper assessment of the TB has not been done. This study is done to assess the patient's perception on TB complication and drug regimen [40-44].

\section{Method}

A cross-sectional survey was done to assess TB-related knowledge, its complications, and control among the participants from the outpatient Pulmonology Department of Owaisi Hospital and Research Center, Hyderabad, India.

\section{Participants}

The data collection is done with help of a questionnaire which contains two different parts that is

1) Knowledge on TB disease,

2) Complication and control of TB. The study includes 1006 patients from the out-patients from Pulmonology department which were previously diagnosed for tuberculosis. The patient's response in the survey study was assessed on perception of TB disease, its complication and control.

\section{Result}

- The above statistical analysis shows that, maximum (59\%) were unsure that the severe complication of Tuberculosis. Participants both (male and female) were unaware about treatment and side effects of the given medicine.

- $\quad 90 \%$ of total participants scared when they had cough with blood and sought immediate treatment. $45 \%$ of total participants did not adhere to the treatment and discontinue it half way. This becomes the prime reason for the gap between the treatment and its adherence.

- $58 \%$ of total participants' belief was that TB is a short lived infectious disease and curable. In Contrast to this $28 \%$ total of participant had opposite negative thought; they told that TB is not at all curable completely. $30 \%$ of total participant thought that 1 or 2 months treatment are sufficient is enough to control TB disease (Tables 1-9).

*Corresponding author: Fazlu Rehman, Global College of Pharmacy, Hyderabad, India, Tel: 09705866965; E-mail: fazal8020@gmail.com

Received November 18, 2016; Accepted January 23, 2017; Published January 27, 2017

Citation: Rehman F, Raoof MA, Srinivasa Rao A, Hasan A, Qurram M (2017) Knowledge about Tuberculosis and its Complication among the Patients in a Teaching Hospital. J Pulm Respir Med 7: 390. doi: 10.4172/2161-105X.1000390

Copyright: @ 2017 Rehman F, et al. This is an open-access article distributed under the terms of the Creative Commons Attribution License, which permits unrestricted use, distribution, and reproduction in any medium, provided the original author and source are credited. 
Citation: Rehman F, Raoof MA, Srinivasa Rao A, Hasan A, Qurram M (2017) Knowledge about Tuberculosis and its Complication among the Patients in a Teaching Hospital. J Pulm Respir Med 7: 390. doi: 10.4172/2161-105X.1000390

Page 2 of 4

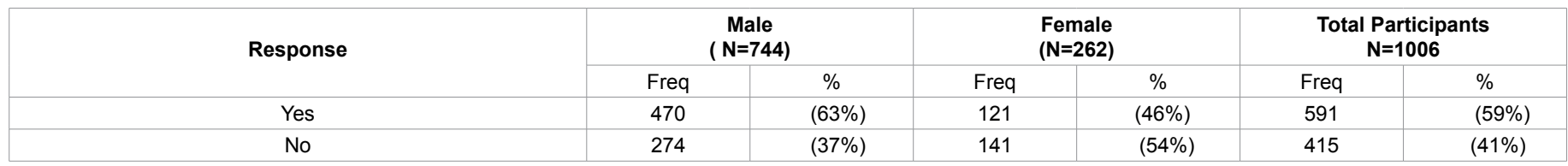

Table 1: Do you know, Tb disease is one of the leading cause of death.

\begin{tabular}{|c|c|c|c|c|c|c|}
\hline \multirow[t]{2}{*}{ Response } & \multicolumn{2}{|c|}{$\begin{array}{c}\text { Male } \\
(\mathrm{N}=744)\end{array}$} & \multicolumn{2}{|c|}{$\begin{array}{l}\text { Female } \\
(\mathrm{N}=262)\end{array}$} & \multicolumn{2}{|c|}{$\begin{array}{l}\text { Total Participants } \\
\qquad N=1006\end{array}$} \\
\hline & Freq & $\%$ & Freq & $\%$ & Freq & $\%$ \\
\hline Yes & 378 & $(51 \%)$ & 72 & $(27 \%)$ & 454 & $(45 \%)$ \\
\hline No & 182 & $(24 \%)$ & 83 & $(32 \%)$ & 262 & $(26 \%)$ \\
\hline Unsure & 184 & $(25 \%)$ & 107 & $(41 \%)$ & 290 & $(29 \%)$ \\
\hline
\end{tabular}

Table 2: Is Tuberculosis contagious?

\begin{tabular}{|c|c|c|c|c|c|c|}
\hline \multirow[t]{2}{*}{ Response } & \multicolumn{2}{|c|}{$\begin{array}{c}\text { Male } \\
(\mathrm{N}=745)\end{array}$} & \multicolumn{2}{|c|}{$\begin{array}{l}\text { Female } \\
(\mathrm{N}=260)\end{array}$} & \multicolumn{2}{|c|}{$\begin{array}{l}\text { Total Participants } \\
\quad \mathrm{N}=1005\end{array}$} \\
\hline & Freq & $\%$ & Freq & $\%$ & Freq & $\%$ \\
\hline Yes & 228 & $(31 \%)$ & 69 & $(26 \%)$ & 297 & $(30 \%)$ \\
\hline No & 98 & $(13 \%)$ & 14 & $(5 \%)$ & 112 & $(11 \%)$ \\
\hline Unsure & 418 & $(10 \%)$ & 179 & $(68 \%)$ & 597 & $(59 \%)$ \\
\hline
\end{tabular}

Table 3: Do you know that TB can cause severe complications?

\begin{tabular}{|c|c|c|c|c|c|c|}
\hline \multirow[t]{2}{*}{ Response } & \multicolumn{2}{|c|}{$\begin{array}{c}\text { Male } \\
(N=744)\end{array}$} & \multicolumn{2}{|c|}{$\begin{array}{l}\text { Female } \\
(\mathrm{N}=262)\end{array}$} & \multicolumn{2}{|c|}{$\begin{array}{l}\text { Total Participants } \\
\qquad N=1006\end{array}$} \\
\hline & Freq & $\%$ & Freq & $\%$ & Freq & $\%$ \\
\hline Yes & 528 & $(71 \%)$ & 182 & $(69 \%)$ & 710 & $(71 \%)$ \\
\hline No & 130 & $(17 \%)$ & 59 & $(23 \%)$ & 189 & $(19 \%)$ \\
\hline Unsure & 86 & $(12 \%)$ & 21 & $(8 \%)$ & 107 & $(11 \%)$ \\
\hline
\end{tabular}

Table 4: Is medication important in controlling TB?

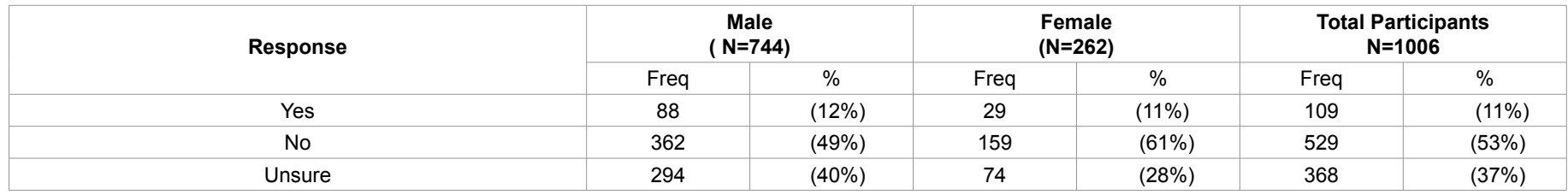

Table 5: Do you know the side effects caused by drug used in treatment of TB?

\begin{tabular}{|c|c|c|c|c|c|c|}
\hline \multirow[t]{2}{*}{ Response } & \multicolumn{2}{|c|}{$\begin{array}{c}\text { Male } \\
(\mathrm{N}=744)\end{array}$} & \multicolumn{2}{|c|}{$\begin{array}{l}\text { Female } \\
(\mathrm{N}=262)\end{array}$} & \multicolumn{2}{|c|}{$\begin{array}{l}\text { Total Participants } \\
\qquad N=1006\end{array}$} \\
\hline & Freq & $\%$ & Freq & $\%$ & Freq & $\%$ \\
\hline Sever consequences of disease & 469 & $(63 \%)$ & 176 & $(67 \%)$ & 645 & $(64 \%)$ \\
\hline Relapse of disease & 162 & $(22 \%)$ & 57 & $(22 \%)$ & 219 & $(22 \%)$ \\
\hline Don't know & 113 & $(15 \%)$ & 29 & $(11 \%)$ & 142 & $(14 \%)$ \\
\hline
\end{tabular}

Table 6: What could be the consequences of incomplete or inappropriate treatment?

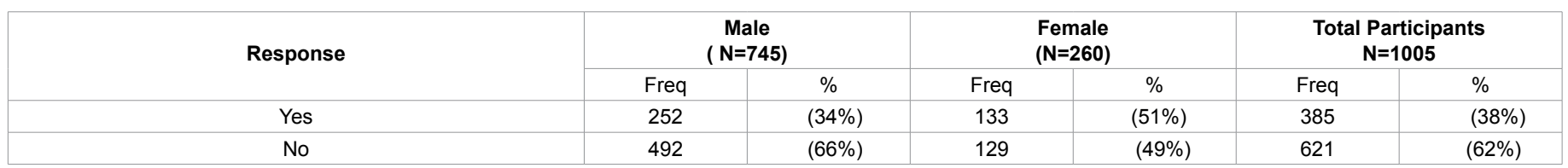

Table 7: Do you keep a record of your medication?

\section{Discussion}

The study shows significant variations in the genders male and female. Male are better informed the causes, transmission of TB, its complication and Control. Maximum patients were unsure about the sever complication of TB and drugs. The result of this study also indicates that intolerance of Anti-tuberculosis drugs due to side effect is still a serious problem in patients. The incidence rate of hepatic dysfunction was found to be the most frequent side effect. Whereas minor ocular and gastrointestinal complications were reported, Rifampicin and isoniazid was the most causative agent of hepatotoxicity. Of all the participants $62 \%$ of the patients stated that they didn't have idea of properly maintain the medical records for their treatment of the disease, this is the main root cause, where TB not under controls.

It was very concerning that there is a tendency to show discrimination towards TB patients, which was shown by this study. A good number of patients told that they are unaware that TB causes 


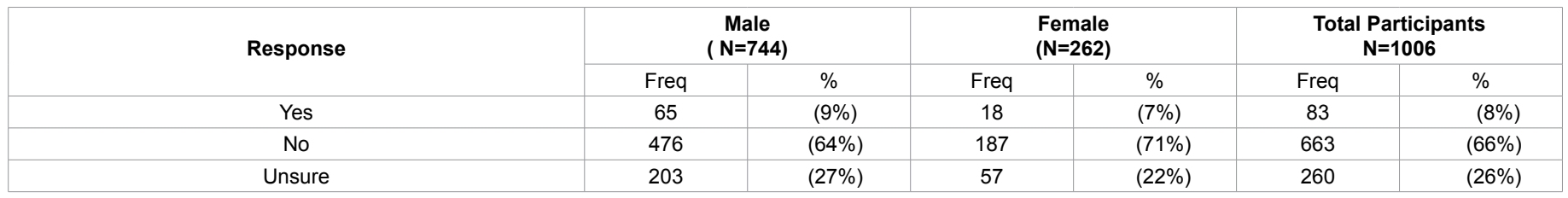

Table 8: Do you know what is Multidrug resistance tuberculosis (MDR-TB)?

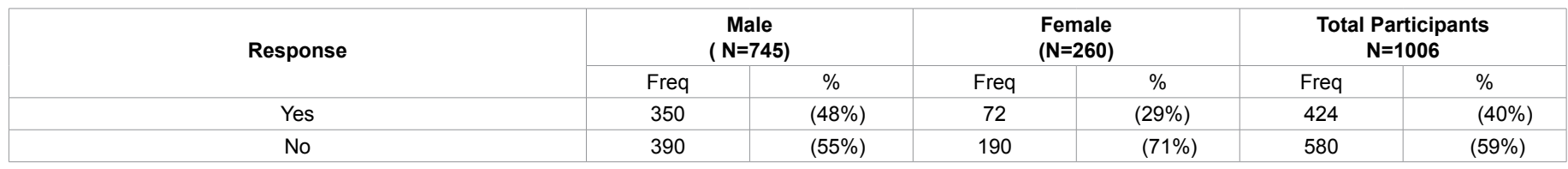

Table 9: After getting a positive MDR-TB test, have you completed given treatment?

severe complications and patients do not maintain any medical history/ records of the disease. In addition, the most alarming event was that patients are unaware of the Multi-drug resistance Tuberculosis (MDRTB) besides. These results, in lack of awareness of drug therapy and its regimen after getting a positive test for MDR-TB test. It was very encouraging as we expect individuals to seek health care as early as possible. However, the patients are very well aware of the side effects of drugs and consequences of incomplete or inappropriate treatment. An attempt could be made in future to improve an awareness and knowledge among TB patients to decrease TB complications and misconceptions, to allay the social stigma attached with it to decrease TB transmission. TB complications includes spinal pain, joint pain in knees and hips, swelling of the membrane of the brain i.e., meningitis, impairment of liver and kidney functions and rarely Heart disorder called cardiac Tamponade. These complications can be overcome by minimizing the drug side effects. This can be done by increasing the awareness for proper usage of medications to prevent MDR-TB. Drug complications can be diminished by increasing immunity of the patients with the help of diet and increasing pulmonary health.

\section{Conclusion}

According to this study analysis, it is clear that a patient does not have clear knowledge regarding the $\mathrm{TB}$, its complication and control. Perfect management of active tuberculosis treatment includes the initiation and the completion of anti-tuberculosis therapy with minimal complication and reduce side effect of anti-tuberculosis drug by closer monitoring of Adverse Drug Reaction (ADR). MDR-TB can be diminished by identifying the drug resistance and by treating the disease with the second line anti-tuberculosis drugs in proper regiment in relapse cases. Thereby inappropriate or incomplete treatment could lead to severe consequences and may leads to death of the patient. Knowledge about pulmonary complication and duration of treatment has to be focused.

\section{References}

1. Nyangulu DS, Harries AD, Kang'ombe C, Yadidi AE, Chokani K, et al. (1997) Tuberculosis in a prison population in Malawi. Lancet 350: 1284-1287.

2. Abebe DS, Bjune G, Ameni G, Biffa D, Abebe F (2011) Prevalence of pulmonary tuberculosis and associated risk factors in Eastern Ethiopian prisons. Int $J$ Tuberc Lung Dis 15: 668-667.

3. Banu S, Hossain A, Uddin MK, Uddin MR, Ahmed T, et al. (2010) Pulmonary Tuberculosis and drug resistance in Dhaka central jail, the largest prison in Bangladesh. PLoS One 5: e10759.

4. Getahun H, Gunneberg C, Sculier D, Verster A, Raviglione M (2012) Tuberculosis and HIV in people who inject drugs: evidence for action for tuberculosis, HIV, prison and harm reduction services. Curr Opin HIV AIDS 7: 345-353.
5. Shah SA, Mujeeb SA, Mirza A, Nabi KG, Siddiqui Q (2003) Prevalence of pulmonary tuberculosis in Karachi juvenile jail, Pakistan. East Mediterr Health J 9: 667-667.

6. http://apps.who.int/iris/bitstream/10665/137094/1/9789241564809_eng.pdf

7. WHO (2014) Drug-resistant TB surveillance \& response supplement. Global Tuberculosis Report.

8. Streicher EM, Müller B, Chihota V, Mlambo C, Tait M, et al. (2012) Emergence and treatment of multidrug resistant (MDR) and extensively drug-resistant (XDR) tuberculosis in South Africa. Infect Genet Evol 1: 686-694.

9. Andrews JR, Shah NS, Weissman D, Moll AP, Friedland G, et al. (2010) Predictors of multidrug-and extensively drug-resistant tuberculosis in a high HIV prevalence community. PLoS One 5: e15735.

10. World Health Organization (2010) Multidrug and Extensively Drug-Resistant TB (M/XDR-TB): 2010 Global Report on Surveillance and Response, World Health Organization, Geneva, Switzerland.

11. Tessema B, Muche A, Bekele A, Reissig D, Emmrich F, et al. (2009) Treatment outcome of tuberculosis patients atGondar, University Teaching Hospital, Northwest Ethiopia. A five-year retrospective study. BMC Public Health 9: 371.

12. Hamusse SD, Demissie M, Teshome D, Lindtjørn B (2014) Fifteen-year trend in treatment outcomes among patients with pulmonary smear-positive tuberculosis and its determinants in Arsi Zone, Central Ethiopia. Global Health Action 7: 25382.

13. Shingadia D, Seddon JA (2014) Epidemiology and disease burden of tuberculosis in children: a global perspective. Infect Drug Resist 7: 153-165.

14. http://www.who.int/mediacentre/factsheets/fs104/en/

15. WHO (2009) WHO Policy on TB Infection Control in Health-Care Facilities, Congregate Settings and Households. WHO/HTM/TB/2009.419, World Health Organization, Geneva, Switzerland.

16. Lawn SD, Wilkinson R (2006) Extensively drug resistant tuberculosis. British Medical Journal 33: 559-560.

17. Revised National Tuberculosis Control Programme Training Manual for Mycobacterium tuberculosis Culture and Drug Susceptibility Testing. Central Tuberculosis Division, New Delhi, India, 2009.

18. Kumar VG, Urs TA, Ranganath RR (2011) MPT 64 Antigen detection for Rapid confirmation of M.tuberculosis isolates. BMC Res Notes 4: 79.

19. Sethi S, Mewara A, Dhatwalia SK, Singh H, Yadav R, et al. (2013) Prevalence of multidrug resistance in Mycobacterium tuberculosis isolates from HIV seropositive and seronegative patients with pulmonary tuberculosis in north India. BMC Infect Dis 13: 137.

20. Paramasivan $\mathrm{CN}$, Bhaskaran $\mathrm{K}$, Venkataraman $\mathrm{P}$, Chandrasekaran $\mathrm{V}$ Narayanan PR (2000) Surveillance of drug resistance in tuberculosis in the state of Tamil Nadu. Ind J Tub 47: 27-33.

21. Trivedi SS, Desai SG (1988) Primary anti-tuberculosis drug resistance and acquired rifampicin resistance in Gujarat. Ind J Tub 69: 37-42.

22. Rawat J, Sindhwani G, Juyal R, Dua R (2009) Five-year trend of acquired antitubercular drug resistance in patients attending a tertiary care hospital at Dehradun (Uttarakhand). Lung India 26: 106-108. 
Citation: Rehman F, Raoof MA, Srinivasa Rao A, Hasan A, Qurram M (2017) Knowledge about Tuberculosis and its Complication among the Patients in a Teaching Hospital. J Pulm Respir Med 7: 390. doi: 10.4172/2161-105X.1000390

Page 4 of 4

23. Jain NK, Chopra KK, Prasad G (1992) Initial and acquired Isoniazid and Rifampicin resistance to $M$. tuberculosis and its implications for treatment. Ind J Tub 39: 121-124

24. Vijay S, Balasangameshwara VH, Jagannatha PS, Saroja VN, Shivashankar B, et al. (2002) Re-treatment outcome of smear positive tuberculosis cases under DOTs in Bangalore city. Ind J Tub 49: 195-220.

25. Paramasivan $\mathrm{CN}$, Venkataraman $\mathrm{P}$, Chandrasekaran $\mathrm{V}$, Bhat $\mathrm{S}$, Narayanan PR (2002) Narayanan, Surveillance of drug resistance in tuberculosis in two districts of South India. Int J Tuberc Lung Dis 6: 479-448.

26. Gopi PG, Vallishayee RS, Appe Gowda BN, Paramasivan CN, Ranganath S et al. (1997) A tuberculosis prevalence survey based on symptoms questioning and sputum examination. Ind J Tub 4: 171-180

27. Ramachandran R, Nalini S, Chandrasekar V, Dave PV, Sanghvi AS, et al. (2009) Surveillance of drug-resistant tuberculosis in the state of Gujarat, India. Int J Tuberc Lung Dis 13: 1154-1160.

28. Singla R, Sharma SK, Mohan A, Makharia G, Sreenivas V, et al. (2010) Evaluation of risk factors for anti-tuberculosis treatment induced hepatotoxicity. Indian J Med Res 132: 81-86.

29. Marra F, Marra CA, Bruchet N, Richardson K, Moadebi S, et al. (2007) Adverse drug reactions associated with first-line anti-tuberculosis drug regimens. Int $\mathrm{J}$ Tuberc Lung Dis 11: 868-875.

30. Javadi MR, Shalviri G, Gholami K, Salamzadeh J, Maghooli G, et al. (2007) Adverse reactions of anti-tuberculosis drugs in hospitalized patients: incidence, severity and risk factors. Pharmacoepidemiol Drug Saf 16: 1104-1110.

31. Qureshi W, Hassan G, Kadri GSM, Khan HQ, Samuel B, et al. (2007) Hyperuricemia and arthralgias during pyrazinamide therapy in patients with pulmonary tuberculosis. Lab Med 38: 495-497.

32. Sharma SK, Balamurugan A, Saha PK, Pandey RM, Mehra NK (2002) Evaluation of clinical and immunogenetic risk factors for the development of hepatotoxicity during antituberculosis treatment. The Am J Respir Crit Care Med 166: 916-919.

33. Jasmer RM, Saukkonen JJ, Blumberg HM, Daley CL, Bernardo J, et al. (2002)
Short course rifampin and pyrazinamide compared with isoniazid for latent tuberculosis infection: A multicenter clinical trial. Ann Intern Med 137: 640-647.

34. Gandhi NR, Nunn P, Dheda K, Schaaf HS, Zignol M, et al. (2010) Multidrug resistant and extensively drug-resistant tuberculosis: a threat to global control of tuberculosis. Lancet 375: 1830-1843.

35. Goyal M, Saunders NA, van Embden JD, Young DB, Shaw RJ (1997) Differentiation of Mycobacterium tuberculosis isolates by spoligotyping and IS6110 restriction fragment length polymorphism. J Clin Microbiol 35: 647-651.

36. Gandhi NR, Shah NS, Andrews JR, Vella V, Moll AP, et al. (2010) HIV coinfectionin multidrug- and extensively drug-resistant tuberculosis results in high early mortality. Am J Respir Crit Care Med 18: 80-86.

37. Kim SJ (2005) Drug-susceptibility testing in tuberculosis: methods and reliability of results. Eur Respir J 25: 564-569.

38. Jain A, Dixit P, Prasad R (2012) Pre-XDR \& XDR in MDR and Ofloxacin and Kanamycin resistance in non-MDR Mycobacterium tuberculosis isolates. Tuberculosis (Edinb) 92: 404-406

39. Bhatter P, Chatterjee A, Mistry N (2012) Mycobacterium tuberculosis Beijing epidemics: a race against mutations? Tuberculosis (Edinb) 92: 92-94.

40. Veen J, Raviglione M, Rieder HL, Migliori GB, Graf P, et al. (1998) Standardized tuberculosis treatment outcome monitoring in Europe. Eur Respir J 12: 505-510.

41. Salami AK, Oluboyo PO (2002) Hospital prevalence of pulmonary tuberculosis and co-infection with human immunodeficiency virus in llorin: a review of nine years (1991-1999). West Afr J Med 21: 24-27.

42. Malhotra R, Taneja DK, Dhingra VK, Rajpal S, Mehra M (2002) Awareness regarding tuburculosis in a rural population of Delhi. Indian J Community Med 27: 62-68.

43. Ali SS, Rabbani F, Siddiqui UN, Zaidi AH, Sophie A, et al. (2003) Tuberculosis: do we know enough? A study of patients and their families in an out-patient hospital setting in Karachi, Pakistan. Int J Tuberc Lung Dis 7: 1052-1058.

44. Yadav SP, Mathur ML, Dixit AK (2006) Knowledge and attitude towards tuberculosis among sandstone quarry workers in desert parts of Rajasthan Indian J Tuberc 53: 187-195. 